\title{
Ian Roy
}

\section{The English Republic, 1649-1660: the view from the Town Hall}

The duke of Newcastle, who before the civil war had been governor of the Prince of Wales, offered some sage advice to his royal charge, now Charles II, on his restoration to the throne in 1660 . In a classic statement of political reaction, which deserves to be better known, he provided a commentary, at once perceptive and prejudiced, on the factors which had led to the civil war and the downfall of the monarchy, and how best they could be avoided in the future. Among his recommendations were that London 'that rebellious city' - be firmly curbed by means of a new charter and the strengthening of the Tower; that university education be restricted to the sons of the gentry; and that religious uniformity - the old church, its hierarchy and discipline - be reimposed. In particular the patronage by the laity of Puritan lectureships, argued Newcastle, had been politically dangerous to Charles's father. „These lecturers have preached your Majesty out of your kingdoms." In the late troubled times artisans and other low-born persons - and, even worse, their wives and servants - had set up conventicles on the ruins of the old church and had sought God through scripture without benefit of clergy: „The Bible in English under every weaver's and chambermaid's arm hath done us much hurt. ${ }^{\text {1 }}$

Chief among the nation's institutions which had allowed this to happen were the incorporated towns, with their many ancient liberties and their tradition, in some cases, of religious nonconformity. „For corporations, I see no reason why there should be so many, for why should tanners and shoemakers not be contented to be governed by the same way that lords, gentlemen and good yeomen and freeholders are, which is by the known laws of the kingdom, by the judges and justices of peace: but these townsmen must be exempted by their charter. The truth is that every corporation is a petty free state against monarchy, and they have done your Majesty more mischief in these late disorders with their lecturers than anything else hath done."

Was Newcastle correct in his view of recent history? Did the towns in England merit the description 'petty free states', and did they practice a form of government, and patronise a kind of preaching, incompatible with monarchy? Did they aid the es-

${ }^{1}$ S. A. Strong, A Catalogue of Letters and other Historical Documents at Welbeck (London 1903) 176-177, 185, 188.

2 Ibid., 206. 
tablishment of the republican regime and support it during its life? To examine these and other questions it might be useful to look at the experience of a handful of towns in the period.

The cities of Gloucester, Oxford and Worcester were not in the front rank of English towns; they were county towns, not provincial capitals, with 8000 inhabitants on average. They were dwarfed by London itself. England was not a highly urbanised society in the seventeenth century: only $17 \%$ of the population lived in 'towns' (places of over a thousand inhabitants), and half of those lived in London, which was well set upon its career, by the middle of the century, of becoming the largest city in Europe ${ }^{3}$. It was ten times bigger than the next largest town, and it has been calculated that one fifth of all Englishmen and women had some experience of London life ${ }^{4}$. Indeed to trace the urban view of the Interregnum in any satisfactory manner it should be necessary to say something about the nation's capital: but the history of London under the republic has yet to be written. We must rest content for the moment with a sample of the middling sort among towns.

Towns, even of the size of the three above, were of increasing importance in Tudor and Stuart England. Although the population as a whole remained largely rural and in social and tenurial terms dependent on gentry landlords, the population of most towns was rising, and the services offered by these urban centres becoming more complex and diverse. There were 5-600 market towns in England, serving an area within a ten mile or so radius of the town hall. The larger towns possessed a wide range of occupational skills among its inhabitants: the members of Oxford's common council represented 43 different trades alone ${ }^{3}$. County towns, which were also the seats of bishops, were the political and ecclesiastical centres for a wide area. Political recognition by the government of the day of the importance of towns can be seen in the steadily increasing number which received charters of incorporation, granting them a degree of selfgovernment. Elizabeth had granted twenty-six royal charters during her reign, James and Charles (to 1637) a further forty-nine ${ }^{6}$.

Several towns claimed county status and their leading citizens - usually the twelve or thirteen strong groups of aldermen - acted as justices of the peace, deputy lieutenants in charge of the militia, sheriffs, coroners and clerks of the market; the mayor's court heard a wide range of cases. Most, by this date, were closed corporations, in which elections to office were not open to all freemen of the borough or even to all councillors. There was a general trend to oligarchic government in the boroughs, and they could scarcely be accused of practicing local democracy in defiance of the monarchical state in the seventeenth century. The urban elites emphasized their own and their towns' wealth and dignity, and the civic year was marked by nomination and election banquets, speeches and sermons, processions and pageantry. Annual cere-

${ }^{3}$ P. Clark and P. Slack, English Towns in Transition, 1500-1700 (Oxford 1976).

4 Ibid., chap. 5.

'Ibid., chap. 2; M. G. Hobson and H. E. Salter, Oxford Council Acts, 1626-1665 (Oxford 1933) XIII-XIV.

6 J. Richardson, The Local Historian's Encyclopedia (New Barnet 1974); C. Cook and J. Wrougbton, English Historical Facts, 1603-1688 (London 1980). 
monies of this kind, strict rules governing the conduct of business in the council chamber, the wearing of scarlet robes by the aldermen and black or purple gowns by the councillors, all reinforced the selfesteem of the city's rulers. Civic pride and unity were embodied in the building, very often, of a new and expensive town hall, a structure which might cost a small community a great deal of money but in which the many functions of the ruling body could take place. A fine town hall of reasonable size might double not only as council chamber and court room, but as market place, school room, prison, record office, kitchen and armoury ${ }^{7}$. A further recognition of the status of towns was the growing number which sent representatives to Parliament in the period; there were 401 borough M.P.s by 1640 . While threequarters of enfranchised boroughs returned neighbouring country gentry or prominent outsiders to Westminster, several of the largest, including usually the three under consideration, chose their own leading citizens. They account for the sixty or so M.P.s of merchant stock in the Long Parliament in $1640^{8}$.

The privileges granted by the sovereign, the instructions their rulers received regularly and directly from the Privy Council, and the presence of their representatives at Westminster, ensured that the relationship between the town halls and the centre would be close; and it was normally harmonious. Their 'liberties' depended on royal favour: and the confirmation of their local jurisdiction, and their right to elect M.P.s, was not a matter of political controversy before the civil war. The magistrates in the cities, as in the counties, looked to the king for guidance. Where there were unpopular demands they might complain, and their standing locally might depend on the resistance offered and the concessions wrung from the government. With the exception of London no town could resist the king's wishes for long. No provincial city in England was comparable to the great urban centres in the Netherlands or the German states. The towns we are dealing with were not like Ghent, „a little republic in all but name ${ }^{\text {“ }}$ and able and willing to dispute its share of taxation with the Emperor himself ${ }^{9}$. No town hall thought to challenge the government of Charles I directly, on the question of ship money, although there were numerous quarrels over the amount to be paid, with neighbouring authorities. In general the corporations held fast to their charters and the limited but useful autonomy which they allowed.

\section{II}

If there was no open challenge to the central government on major political and fiscal matters, there was, however, plenty of combustible material locally for petty but bitter disputes. Most often these arose over rival jurisdictions which competed with the city authorities' desire to bring order and good government to the area within their walls and to control appointments to city churches, schools and hospitals. In a cathe-

\footnotetext{
'I am grateful to Professor Robert Tittler for this information.

${ }^{8}$ M. F. Keeler, The Long Parliament, 1640-1641 (Philadelphia 1954) 23.

${ }^{9} J$. L. Motley, The Rise of the Dutch Republic (London n.d.) I.61.
} 
dral city the college close, centrally sited, was outside the jurisdiction of the city, and the inhabitants there, who increasingly were wealthy members of the gentry, professional classes and clergy, paid their taxes to the county not the city. The property rights of neighbouring county gentry occasionally conflicted with the cherished privileges of the city. At Chester there was a long-standing dispute over the Gloverstone, an area of the county round the castle walls, as well as over the cathedral precincts and the rights of the mayor there ${ }^{10}$. At Liverpool the quarrel with the lord of the manor centred on his mill and claims to the ferry over the Mersey ${ }^{11}$. There was an equally contentious and long running conflict between the city of Gloucester and the leading families of the 'inshire', that part of the county which had, since 1483, come under the jurisdiction of the city. The gentry claimed that the policies pursued by the city had led to economic decline, and that they bore a disproportionate share of the city's taxation $^{12}$.

The major dispute at Gloucester, however, was over religion, and in this it was typical of several cathedral cities in the period. The city had long enjoyed the reputation of being zealously Protestant. Pious laymen had long made provision for extra lectureships, so that sermons could be heard in the parish churches on Sundays and market days. Late in the 1630 s it was noted that some local Puritans were wearing their hair short and keeping their hats on in church; some were sending their sons to Calvinist Scotland to complete their education, rather than Laudian Oxford. Certainly a Gloucester curate made contact with the Covenanters in $1638^{13}$. In 1640 the city may have planned to send one hundred colonists to Puritan New England ${ }^{14}$. The town hall itself came to be dominated by Puritans who were anxious to throw into the battle against poverty and ignorance in their crowded and economically depressed community all the resources, material and spiritual, which could be spared. One such was Alderman Thomas Pury, who had entered the common council a short time after William Laud, as Dean of the Cathedral chapter, had begun to introduce those 'innovations' in religious practice which so upset traditional Calvinists. Pury's own family, of clothiers, had long been associated with charitable and pious benefactions in the city, and with holding office ${ }^{13}$. Thomas, a clothier turned country solicitor (he had attended neither university nor inn of court), led the fight to retain the city's patronage of a well known lecturer, John Workman, who had been suspended, excommunicated and then imprisoned by the ecclesiastical authorites in the city, no doubt at the prompting of Laud.

${ }^{10}$ A. M. Jobnson, Some aspects of the political, constitutional, social and economic history of the City of Chester, 1550-1662 (Unpubl. Oxford Univ. D. Phil. thesis 1971) 18, 36-89.

${ }^{11} \mathrm{~J}$. A. Picton, City of Liverpool. Selections from the Municipal Archives and Records (Liverpool 1883) 132-133.

${ }^{12}$ G. Davies (ed.), Autobiography of Thomas Raymond and memoirs of the family of Guise of Elmore, Gloucestershire (Camden 3rd ser., vol. 28, 1917) 104; P. Clark, "The Ramoth-Gilead of the Good": Urban Change and Political Radicalism at Gloucester, 1540-1640, in: P. Clark, A. G. $R$. Smith, and N. Tyacke (eds.), The English Commonwealth, 1547-1640 (Leicester 1979).

${ }^{13}$ Calendar of State Papers Domestic, 1639, 490; Clark, Radicalism at Gloucester, 185.

14 Ibid., 186.

${ }^{15} \mathrm{~J}$. Wasbbourn (ed.), Bibliotheca Gloucestrensis: a collection of scarce and curious tracts relating to ... Gloucester (Gloucester 1825) CLXIV. 
Among other misdemeanours he was accused of praying for the States of Holland and the king of Sweden ahead of Charles I. When the council retained his services and awarded him a small pension the leading magistrates, including Pury, were brought before the Court of High Commission by the Archbishop and fined. The case cost the city $£ 200$, about a third of its annual income ${ }^{16}$.

What was at issue, here and in other urban communities, was not just the religious complexion of the lecturer - although that was clearly important - but the dissatisfaction of the city elite with the inability of the established church to meet the spiritual needs of the inhabitants. The many parishes - eleven in Gloucester, for a population within the old city of 5000 - were much too poor to attract competent clergy, and few were able or willing to preach, and the vast cathedral, with its rich, pluralist prebends and unqualified vicars-choral ('singing men'), was too rich, owning as much land as the city itself and desiring to monopolise as much of the worship within the city as possible. For many at the town hall a Puritan reformation, where evangelical preachers and learned schoolmasters were supported by the godly magistrates, was the essential basis for the setting up of a true civic commonwealth, which could deal effectively with the most pressing problems of their little society.

The experience of Gloucester can be paralleled elsewhere. At Norwich the Laudian bishop came into conflict with a Puritan party among the leading citizens, anxious for reform ${ }^{17}$. At York the clergy's new role as justices of the peace upset the corporation ${ }^{18}$. At Chichester, too, the cathedral close and its separate privileges was resented by the townsmen ${ }^{19}$. At Worcester the Dean and Chapter objected to the city's desire to appoint a lecturer (who would be, they claimed, 'chosen by shopkeepers'); no doubt the city was mindful of the fact that a fifth of the local clergy were non-resident pluralists. The ill feeling between the cathedral and the town hall came to a head over a comparatively trivial matter, the seating arrangements made for the aldermen and their wives in the cathedral, considered inadequate to the dignity of 'the senators' in their scarlet robes. As at Gloucester it was not the bishop who was objected to (neither was a Laudian), but the cathedral authorities ${ }^{20}$.

If Laud had a small part to play in the quarrel at Gloucester, he had a much larger role at his own university, Oxford, in the 1630s. As Chancellor he turned it into a model of Laudian practice and belief, and through his agents reasserted the university's old rights over the townsmen - to control the market, see to the night watch, demand the annual penance - on St Scholastica's day - from the mayor and leading citizens for past misdemeanors. But while the colleges were growing and prospering un-

${ }^{16}$ Clark, 186; C. Hill, Society and Puritanism in pre-Revolutionary England (London 1969) 103; Workman's widow was still subsidized by the city chamber in 1656, Gloucester Record Office, Corporation minute book, 1632-56, 886; State Trials (1816) IV. 477-479.

${ }^{17}$ J. T. Evans, Seventeenth-Century Norwich (Oxford 1979) 85-102.

18 State Trials, IV. 426.

19 A. J. Fletcher, A County Community in Peace and War: Sussex, 1600-1660 (London 1975) 235-237.

${ }^{20}$ S. Bond (ed.), The Chamber Order Book of Worcester, 1602-1650 (Worcs. Hist. Soc., new ser., vol. 8, 1974) 45-47. 
der this regime so too was the city, whose privileges antedated those of the university. It rose to the challenge. Tempers were inflamed when 'images' were introduced not only in the university church but by a new Laudian incumbent in the citizens' own church, where for many years the corporation had hired its own lecturers. The city took its case to court and lobbied hard through Laud's opponents on the Privy Coun$\mathrm{cil}^{21}$. Playing a role comparable to that of Pury at Gloucester was Alderman (Mayor in 1636-37) John Nixon, a prominent mercer, experienced councillor, since 1622, and notable Puritan. He and other sober-sided, wealthy citizens, many of whom owned the finest new houses in the city, must have been outraged when Laud accused them personally, during these legal proceedings, of disorderly and drunken conduct in their mayoral elections. By 1640 they had spent a great deal of money and had lost their case $^{22}$.

\section{III}

If these minor local disputes were characteristic of the decade before the civil war, they did not amount to a challenge, on the part of the corporations studied, to the authority of the king himself. It would not be legitimate to conclude that the cumulative effect of a host of such squabbles must inevitably lead to great national conflict. The civil war did, however, require men to take sides and the choice they made would be influenced by their recent religious and political experience; and disputes left unresolved could be carried on under the new banners of King and Parliament. It gave the protagonists of the earlier conflicts a wider, even a national arena, in which to work. The experience of the cities under consideration in the 1640 s was varied, but in all the men and the issues already discussed played a part.

The city of Gloucester's role in the war is among the best known examples of this. Under the leadership of Thomas Pury, elected M.P. for the city in 1640, and an almost united common council, it willingly anticipated the war; unlike the majority of towns it improved its old defences, bought in arms from London, and opened its gates to the forces of Parliament ${ }^{23}$. Pury played a vital role at Westminster, persuading his fellow M.P.s of the strategic importance of the city, coordinating the work of supply, and publicising its case in the London press. He was in the embattled city, however, at the moments of most acute crisis, in 1643 and 1651, when he donned the armour of an infantry captain, at the age of sixty, alongside his $\operatorname{son}^{24}$. At the famous siege of 1643 ,

${ }^{21}$ P. Seaver, The Puritan Lectureships (Stanford, Calif. 1970) 92-93, 112-114; State Trials, IV. 434-435, 474-475; Victoria County History, Oxfordshire, IV, The City of Oxford, 155-173, 177178.

22 Ibid., 145.

${ }^{23}$ Washbourn, Bibliotheca Gloucestrensis, 6-12; Commons Journals, II. 673; Historical Manuscripts Commission 6th Report, 160, 13th Report, I. 61-62, 67, 71, 78; Calendar of the Committee for the Advance of Money, 1501; G. R. O., Town clerk's book, f.193.

${ }^{24}$ C. J., II. 668, III. 241, 492, IV. 536, 591, 606; Wasbbourn, Bibliotheca Gloucestrensis, XXI, LI, 207-208, 216, 229-232, 324, 337, 375, 386, 402-411, 419-423; G. R. O., Letter book, 1640-60, 35. 
when the city defied the king himself at the head of his army - in battle array and with banners unfurled - the old divisions between the magistrates and the inhabitants of the cathedral close were again apparent. It must have been known to the defenders that a strong party within the close and some neighbouring parishes - not to mention some of the county gentry beyond the walls - were only too anxious to open the gates to the king. The Cavaliers had listed over a hundred inhabitants whose houses were to be spared in the event of an assault on the rebellious city ${ }^{25}$.

The relief of Gloucester on 5 September 1643 was a turning point of the war, not to be forgotten by either side. The day was kept thereafter with annual solemnities by the city council, and feasts by the guilds; commemorative verses were printed; the learned town clerk, John Dorney, celebrated its 'wonderfull deliverance' in speeches rich in biblical and classical citation. The south gate of the city, laid low by the besiegers, was promptly rebuilt and inscribed: „A City assaulted by man and saved by God"26. The magistrates had played a full part in the success of this year. The council had met more than $50 \%$ more frequently than usual (See Table 1, on the number of council meetings per year); it had displayed remarkable cohesion under fire and devotion to the cause of God and of the Commonwealth'. Few citizens deserted the city despite the inevitable privations suffered. Even at the height of the siege, Dorney noted, "holy duties' had been performed and sermons attended by large congregations: evangelical preachers flocked to the city as a refuge during the war ${ }^{27}$.

Gloucester's ruling elite had worked hard to preserve their authority and to promote a godly reformation, without which - as no doubt countless sermons reminded them the city was kept in vain. But other towns found that the forces of division and near anarchy unleashed in the 1640 s were too strong to be contained. Civic unity shattered under the impact of civil war. Gloucester remained a maiden city, but its 'sister cities', Bristol, Hereford and Worcester, changed hands twice during the war, and suffered accordingly. Worcester was to undergo a further tribulation on the invasion of Charles II and the Scots in 1651. A petition to Parliament after this experience excused the citizens for conforming to the occupying force; they would otherwise have been 'slaves to the soldiers'28. Each change of government brought a purge of the council, and division in the ranks of the councillors. Although at first a kind of aldermanic solidarity might delay or limit this process - at Oxford, for instance, casualties among councillors in the first two years of Royalist occupation were more the result of typhus and plague than political exclusion: see Tables 2 and 3, where 43 departures are recorded for 1642-44, a third of total membership - the effect of several violent changes of control was cumulative. Most Oxford councillors did not follow John Nixon into self-imposed exile in London when the king set up his headquarters in the city: as tradesmen

${ }^{25}$ British Library, Harl. MS. 6804, f. 118.

${ }^{26} \mathrm{~J}$. Dorney, Certain Speeches made upon the day of the yearly election of officers in the City of Gloucester (London 1653) prelim. verses, 1-10; public thanksgiving decreed, Corp. minute book, 381; tanners' company annual expenses, GCL 28652.

${ }_{27}$ Wasbbourn, Bibliotheca Gloucestrensis, 222, 226, 227-228; Dorney, Certain Speeches, 71-72.

${ }^{28}$ Ibid., 22, 71; post-1651 petition from mayor of Worcester to committee for the advance of money, Public Record Office, SP 24/86. 
Table $1:^{*}$ Number of council meetings per year

Year from Michaelmas to Michaelmas

\begin{tabular}{|c|c|c|c|}
\hline Year & Gloucester & Oxford & Worcester \\
\hline $1635 / 6$ & 14 & 15 & 13 \\
\hline $1636 / 7$ & 13 & 13 & 9 \\
\hline $1637 / 8$ & 17 & 20 & 11 \\
\hline $1638 / 9$ & 22 & 14 & 9 \\
\hline $1639 / 40$ & 21 & 15 & 15 \\
\hline $1640 / 1$ & 24 & 18 & 14 \\
\hline $1641 / 2$ & 20 & 10 & 14 \\
\hline $1642 / 3$ & 37 & 18 & 25 \\
\hline $1643 / 4$ & 27 & 14 & 23 \\
\hline $1644 / 5$ & 26 & 20 & 24 \\
\hline $1645 / 6$ & 27 & 18 & 35 \\
\hline $1646 / 7$ & 39 & 20 & 17 \\
\hline $1647 / 8$ & 18 & 15 & 17 \\
\hline $1648 / 9$ & 26 & 17 & 17 \\
\hline $1649 / 50$ & 27 & 14 & 13 \\
\hline $1650 / 1$ & 24 & 16 & 4 \\
\hline $1651 / 2$ & 21 & 14 & 2 \\
\hline $1652 / 3$ & 21 & 14 & 6 \\
\hline $1653 / 4$ & 25 & 16 & 9 \\
\hline $1654 / 5$ & 27 & 12 & 7 \\
\hline $1655 / 6$ & 23 & 13 & 9 \\
\hline $1656 / 7$ & 23 & 13 & 13 \\
\hline $1657 / 8$ & 20 & 12 & 9 \\
\hline $1658 / 9$ & 13 & 23 & 7 \\
\hline $1659 / 60$ & 20 & 26 & 6 \\
\hline $1660 / 1$ & 31 & 22 & 13 \\
\hline $1661 / 2$ & 30 & 21 & 14 \\
\hline $1662 / 3$ & 13 & 21 & 10 \\
\hline $1663 / 4$ & 21 & 19 & 8 \\
\hline $1664 / 5$ & 11 & 26 & 9 \\
\hline Total & 681 & 509 & 382 \\
\hline Median & $22 / 23$ & 16 & 12 \\
\hline
\end{tabular}

* For this and the following tables I am much indebted to my former research assistant, Dr Stephen Porter.

they were closely tied to the local market for their goods. When the city surrendered to Parliament most of the ruling body who had survived the hazards of the war were politically compromised, and Parliament ordered that those who had been active for the king should be debarred from office; later that they should not be able to vote in council elections ${ }^{29}$. In 1647 a petition from some citizens objected to the election of a 'malignant', and Nixon, who had just completed a term as mayor, was ordered to con-

${ }^{29}$ C. H. Firth and R. S. Rait (eds.), Acts and Ordinances of the Interregnum, 1642-1660 (London 1911) I. 1009, 1023. 
Table 2: Departures (including temporary departures) from city councils as a percentage of current membership in each year

\begin{tabular}{lccc}
\hline Year & Gloucester & Oxford & Worcester \\
\hline $1635 / 6$ & 3,5 & 4,9 & 6,9 \\
$1636 / 7$ & 15,1 & 3,4 & 4,2 \\
$1637 / 8$ & 9,4 & 4,2 & 2,8 \\
$1638 / 9$ & 7,7 & 0,8 & 2,8 \\
$1639 / 40$ & 4,2 & 6,5 & 9,7 \\
$1640 / 1$ & 1,9 & 4,0 & 4,2 \\
$1641 / 2$ & 3,8 & 1,6 & 5,6 \\
$1642 / 3$ & $\mathbf{n} . d$. & 21,4 & 9,7 \\
$1643 / 4$ & 5,9 & 13,4 & 12,5 \\
$1644 / 5$ & 5,6 & 8,3 & 6,9 \\
$1645 / 6$ & 5,6 & 6,7 & 6,9 \\
$1646 / 7$ & 9,6 & 3,5 & 4,2 \\
$1647 / 8$ & 5,9 & 17,0 & 4,2 \\
$1648 / 9$ & 2,0 & 5,9 & 13,9 \\
$1649 / 50$ & 2,0 & 1,9 & 5,6 \\
$1650 / 1$ & 0 & 2,7 & 15,3 \\
$1651 / 2$ & 5,6 & 4,3 & 5,6 \\
$1652 / 3$ & 3,5 & 8,1 & 15,3 \\
$1653 / 4$ & 3,6 & 3,2 & 8,3 \\
$1654 / 5$ & 10,2 & 5,6 & 1,4 \\
$1655 / 6$ & 0 & 5,5 & 11,1 \\
$1656 / 7$ & 0 & 3,2 & 1,4 \\
$1657 / 8$ & 7,0 & 1,6 & 8,3 \\
$1658 / 9$ & 3,5 & 3,8 & 2,8 \\
$1659 / 60$ & 7,3 & 5,6 & 20,8 \\
$1660 / 1$ & 0 & 3,6 & 5,6 \\
$1661 / 2$ & 42,4 & 28,3 & 22,2 \\
$1662 / 3$ & 31,8 & 10,4 & 5,6 \\
$1663 / 4$ & 2,0 & 10,8 & 6,9 \\
$1664 / 5$ & 0 & 8,9 & 5,6 \\
\hline As & & & \\
\hline
\end{tabular}

Assuming a full council membership of 72 at Worcester every year.

tinue $^{30}$. Because of this direct political interference, and the high mortality among Oxford inhabitants during the war, those who now joined Nixon on the aldermanic bench were considerably his inferior in wealth, status and town hall experience. The governments of the 1650 s would depend very much on one man. Similarly at Worcester a hitherto obscure clothier and common councillor - not even a member of the twenty-four before the war - Edward Elvins, who had headed a kind of government in exile, probably at Warwick, while the city was a Royalist garrison, was set up by Parliament as mayor in 1646 , "there being no other that they would confide in". There was a plan to continue him in office in the following year "notwithstanding charter or cus-

${ }^{30}$ Bodleian Library, Wood F 35, f.13; Oxford Council Acts, 151. 
Table 3: Annual Number of departures from city councils

Percentage in each year of total number, 1635-1665

\begin{tabular}{|c|c|c|c|c|c|c|}
\hline & \multicolumn{2}{|c|}{ Gloucester } & \multicolumn{2}{|c|}{ Oxford } & \multicolumn{2}{|c|}{ Worcester } \\
\hline & Number & $\%$ of total & Number & $\%$ of total & Number & $\%$ of total \\
\hline $1635 / 6$ & 2 & 1,8 & 6 & 2,4 & 5 & 2,9 \\
\hline $1636 / 7$ & 8 & 7,1 & 4 & 1,6 & 3 & 1,8 \\
\hline $1637 / 8$ & 5 & 4,5 & 5 & 2,0 & 2 & 1,2 \\
\hline $1638 / 9$ & 4 & 3,6 & 1 & 0,4 & 2 & 1,2 \\
\hline $1639 / 40$ & 2 & 1,8 & 8 & 3,2 & 7 & 4,1 \\
\hline $1640 / 1$ & 1 & 0,9 & 5 & 2,0 & 3 & 1,8 \\
\hline $1641 / 2$ & 2 & 1,8 & 2 & 0,8 & 4 & 2,4 \\
\hline $1642 / 3$ & 6 & 5,4 & 28 & 11,1 & 7 & 4,1 \\
\hline $1643 / 4$ & 3 & 2,7 & 15 & 5,9 & 9 & 5,3 \\
\hline $1644 / 5$ & 3 & 2,7 & 9 & 3,6 & 5 & 2,9 \\
\hline $1645 / 6$ & 3 & 2,7 & 7 & 2,8 & 5 & 2,9 \\
\hline $1646 / 7$ & 5 & 4,5 & 4 & 1,6 & 3 & 1,8 \\
\hline $1647 / 8$ & 3 & 2,7 & 19 & 7,5 & 3 & 1,8 \\
\hline $1648 / 9$ & 1 & 0,9 & 6 & 2,4 & 10 & 5,9 \\
\hline $1649 / 50$ & 1 & 0,9 & 2 & 0,8 & 4 & 2,4 \\
\hline $1650 / 1$ & 0 & 0 & 3 & 1,2 & 11 & 6,5 \\
\hline $1651 / 2$ & 3 & 2,7 & 5 & 2,0 & 4 & 2,4 \\
\hline $1652 / 3$ & 2 & 1,8 & 10 & 4,0 & 11 & 6,5 \\
\hline $1653 / 4$ & 2 & 1,8 & 4 & 1,6 & 6 & 3,5 \\
\hline $1654 / 5$ & 6 & 5,4 & 7 & 2,8 & 1 & 0,6 \\
\hline $1655 / 6$ & 0 & 0 & 7 & 2,8 & 8 & 4,7 \\
\hline $1656 / 7$ & 0 & 0 & 4 & 1,6 & 1 & 0,6 \\
\hline $1657 / 8$ & 4 & 3,6 & 2 & 0,8 & 6 & 3,5 \\
\hline $1658 / 9$ & 2 & 1,8 & 5 & 2,0 & 2 & 1,2 \\
\hline $1659 / 60$ & 4 & 3,6 & 8 & 3,2 & 15 & 8,8 \\
\hline $1660 / 1$ & 0 & 0 & 5 & 2,0 & 4 & 2,4 \\
\hline $1661 / 2$ & 25 & 22,3 & 39 & 15,4 & 16 & 9,4 \\
\hline $1662 / 3$ & 14 & 12,5 & 12 & 4,7 & 4 & 2,4 \\
\hline $1663 / 4$ & 1 & 0,9 & 12 & 4,7 & 5 & 2,9 \\
\hline \multirow[t]{2}{*}{$1664 / 5$} & 0 & 0 & 9 & 3,6 & 4 & 2,4 \\
\hline & 112 & 100,4 & 253 & 100,5 & 170 & 100,3 \\
\hline
\end{tabular}

tom": but, unlike Nixon, he was in the event excused ${ }^{31}$. Those who joined him in the government of the city, particularly after the disaster of 1651 had compromised a further group, were not drawn from the inner circle of the pre-war ruling elite. As at Oxford, and unlike Gloucester, the principal citizens of the Interregnum period were new men.

31 Lords Journals, IX. 430, 437; P. Styles, The City of Worcester during the Civil Wars, 1640-1660, in: idem, Studies in Seventeenth Century West Midlands History (Kineton 1978) 213-257. 


\section{IV}

Nixon and Elvins had been brought back to their cities in the baggage of the New Model Army, which had defeated the king in battle: Pury and his colleagues had powerfully and directly contributed to that defeat. There can be no doubt of their commitment to the cause of Parliament, nor that it was influenced by their experience of the 1630 s in conflict with the Laudian church. Both Nixon and Pury were involved in the destruction of the old church during the war. As a member of the Long Parliament Pury had welcomed the Root and Branch bill - to eradicate the episcopal church 'root and branch' - in 1641. He was an important witness at Laud's trial, when the archbishop's treatment of John Workman, the Gloucester lecturer, was examined. Nixon provided evidence of Laudian innovations at Oxford ${ }^{32}$. They, and others brought to power by the new post-civil war regime, had demonstrated their allegiance to Parliament and their hostility to the innovations of the 1630s, and their willingness to oppose the Cavaliers. But were they equally committed to the overthrow of the monarchy? To the king's supporters, like the duke of Newcastle, this question would appear redundant, for were not these the men who had openly defied Charles I at the height of his power, at the head of his army, and had destroyed his ecclesiastical lieutenant, William Laud. But for those who had sided with Parliament in the war it was not so simple. Parliament claimed that it was defending 'liberty and property' against 'popery and tyranny', and was acting in the name of the king in so doing. Charles Stuart was, for the moment and regrettably, captured by evil advisers; it was the duty of his subjects to release him. The mayor of Gloucester, according to Dorney, was to keep the city on behalf of the king, ,always remembering that he is also entrusted with the keeping of the gates by the Parliament, where his [the king's] power resides, though his person is absent ${ }^{\text {"33 }}$. Arguments of this kind may be considered feeble and inadequate, as they were by contemporary radicals and Royalists alike; but they helped a large number of moderate men, of varying opinions, to resist the arbitrary acts of the sovereign while satisfying their consciences in so doing. They also made it easier for religious reformers to distinguish between their enthusiastic attack on the government of the church and any attempt to alter the government of the nation by king, lords and commons. It is likely that most of the townsmen whose actions we have been considering in this paper fall into one or other of these categories. They were defenders of the liberties of their boroughs and opponents of Laud; but they were not destroyers of monarchy.

The speeches of town clerk Dorney, at Gloucester's annual mayoral elections, illustrate some of these themes. They were surely designed to appeal to his town hall audience, and to reflect their views. While celebrating the city's heroic role in the war - the mayor and corporation had been styled "the conservators of the Parliament of England" in 1646 - Dorney had been content, as we have seen, to adhere closely to the of-

32 Mr. Thomas Pury Alderman of Gloucester his Speech (London 1641); State Trials, IV. 434-435, 474-475, 477-479.

${ }^{33}$ Wasbboum, Bibliotheca Gloucestrensis, 211, 228; Dorney, Certain Speeches, 15-16. 
ficial, unrevolutionary arguments used to justify resistance to the king. He, and his audience, were clearly taken aback by the execution of Charles I and the establishment of the Commonwealth. Nothing is more eloquent of the lack of political and ideological preparation for these events than the scarcely concealed distress and open bewilderment expressed in his speech welcoming the new mayor in October $1649^{34}$. In defeat the king had attracted a good deal of sympathy: „the pity of the Vulgar gave a greater majesty to his person“, as a leading Parliamentary apologist confessed, and many came to him to receive the royal touch ${ }^{33}$. In these circumstances, Dorney admitted, the king-killing act amazed and perplexed many, „and that not only the vulgar“. Some would have preferred a treaty which would have guaranteed the liberties they had fought for. The abolition of the monarchy, which had followed the king's trial, had appeared to be unprecedented, and the town clerk learnedly searched the chronicles of England for historical examples; as the Saxon heptarchy had once come to an end, he argued, so now a period was being put to monarchy in England as a whole ${ }^{36}$. What he conspicuously failed to do, and his insularity in this respect was typical of the nation as a whole, was to consider whether there might be working models of republicanism abroad. If Workman, the Gloucester lecturer, had prayed for the States of Holland before the civil war, it was the States as a champion of Protestantism, not republicanism (as its conjuncture with the king of Sweden indicates), that he did so. In conclusion, Dorney could do no better than base his argument on the de facto nature of government, and the need to obey God's will. As Providence had brought these great changes about they would either deserve God's blessing, or not; and ordinary mortals might judge accordingly ${ }^{37}$.

No representative of the three cities in the Long Parliament was a revolutionary, willing to take part in the trial of the king or make an early commitment to the new republic. Only Thomas Pury, senior, of the six M.P.s (his son was also now a M.P.) remained at Westminster continually active for his city so long as the Rump survived; his fellow burgess was also conformist, but inactive. Nixon had already withdrawn, with the permission of the House, to attend to the affairs of Oxford. Worcester appears to have been unrepresented for the next four years; one of its M.P.s was over ninety and it is not certainly known whether he was alive or dead in $1649^{38}$. The commitment of each town council to the new regime, in spite of the work of the Parliamentarian activists, in alliance with the army, was as uncertain and half-hearted. At Norwich, another Puritan city, the Engagement - the oath of loyalty „to the Commonwealth of England as it is now established without a King or House of Lords", which

34 Ibid., 23, 48-51.

35 T. May, A Breviary of the History of the Parliament of England, in: F. Maseres, Select Tracts relating to the Civil Wars in England (London 1815) I. 113.

${ }^{36}$ Dorney, Certain Speeches, 48-50.

${ }^{37}$ Ibid. Dorney hoped for a closer union with the United Provinces to uphold the Protestant cause, in October 1652, some months after hostilities had broken out; ibid., 79.

${ }^{38} M$. Keeler, The Long Parliament, 1640-1641; B. Worden, The Rump Parliament, 1648-1653 (Cambridge 1974) appendix A. 
was to be taken first by civic officers, and then by all adult males who wanted to take part in elections - was only "haphazardly enforced"39. A committee was empowered at Gloucester to tender the oath to the local troops, but there is no sign among the very full minutes of the corporation that it was taken by councillors. If it was, none resigned on that account ${ }^{40}$. The main record of council meetings at Worcester has the laconic entry for February 1650: „A full chamber not appearinge nor above the number of sixteene the act concerning the engagement was read". A full chamber at Worcester was 72. No action was taken against absentees, but of the fourteen departures in the years 1648-50 nine appear to have been political ${ }^{41}$. There is equally little evidence of the enforcement of the loyalty test at Oxford, where in any case the purge of the council had taken place earlier. See tables 2 and 3 for departures.

Acceptance of the new republic, even by the firmest friends of Parliament, was marked by an absence of enthusiasm or revolutionary rhetoric, and it was as well that the political test offered made it easy for most to conform. The attitude of the ruling authorities at Westminster to their local supporters was therefore in line with their approach to the more conservative politicians, officials and clergymen, who had disapproved of their action but might be won over to the new government by its cautious, conciliatory and unradical policies. While many must have wished, locally and nationally, that the settlement could have been achieved in the name of the king, once the deed was done there were many advantages in accepting it. At least the death of Charles I ensured that there was no possibility that he would be set upon his throne again and, after a token period of Presbyterianism, restore the bishops and cathedrals he treasured. The revolution, whatever its shortcomings, had avoided a compromise on those terms. So far as the old controversies between the urban and the ecclesiastical authorities were concerned, the victory of Parliament held out the hope of a judgment in favour of the towns: that victory was secured, for the time being, by the events of 1649.

The corporations had already established close working relations with some of the leading men in Parliament, and as the latter accepted the new regime and took office under it so did the former. Nixon had persuaded Bulstrode Whitelocke, the lawyer who was to become the Commonwealth's equivalent of Lord Chancellor, to be the city's recorder in 1647: in June 1649 he was elected as high steward of Oxford, in place of a peer who was disabled as a Royalist ${ }^{42}$. Gloucester was equally prompt and successful in seeking the patronage and protection of a highly placed official: William Lenthall, Speaker of the House of Commons, conformist rather than revolutionary, accepted the city's offer to become its recorder, and remained active on its behalf throughout the 1650 s. He was able to forewarn the corporation of impending legisla-

${ }^{39}$ Engagement, September 1649 and January 1650 (general subscription), Acts and Ordinances, II. 241-242, 325-329; Evans, Seventeenth-Century Norwich, 183.

40 Wasbbourn, Bibliotheca Gloucestrensis, 388-391.

41 Bond, Chamber Order Book, 458.

${ }^{42}$ Nixon to Whitelocke, February 1647, Longleat House, Whitelocke MS, vol. 9, f. 123; Oxford Council Acts, 143, 164, 431. 
tion, in matters which might affect its welfare ${ }^{43}$. He and Pury played an active role in steering through Parliament the acts the city required. Some of the political support the town halls sought was also military, for the Commonwealth was a republic at war for most of its life, and each of the cities here considered was a garrison until after the defeat of the Scots in 1651 . So long as the local military governor worked with the city magistrates, and not against them - as happened in some cases - their prestige and effectiveness would be reinforced. 'Unity and security' were closely allied at Gloucester, where the governor, Sir William Constable, a Yorkshire baronet, appears to have been an influence for stability ${ }^{44}$. In some towns the local officers joined the ruling body; others were honoured with gifts and favours. With the continued threat of Royalist uprisings and other civil disturbance throughout the 1650 s there was a natural emphasis on the presence of security forces and on the importance of the local militia remaining in politically safe hands. In the elections to the Parliaments of the Cromwellian Protectorate a number of army officers, especially where they had local connections, began to make their appearance as representatives of the cities. Where they also had or claimed kinship with the Protector himself their claims were overwhelming ${ }^{45}$. In all these ways, subtly changing as the political arrangements at the centre were shaped and reshaped during these years, the lines of communication were kept open between the cities and the government.

While the corporations may have deplored the means by which the Commonwealth came to power they were able to establish harmonious relations with the members of the Rump; and it may not be too fanciful to see a correspondence between the ruling body at Westminster and the ruling elites in the town halls. The Commonwealth seal of 1651 (see illustration 1) depicts the Commons in session, and carries the legend, „In the third year of freedom by God's blessing restored“. Henry Marten, one of the few principled republicans and revolutionaries in the House, had persuaded his fellow M.P.s to make at least this gesture to novelty ${ }^{46}$. Along with the translation of their Latin charters and other legal records into English - a task Dorney performed at Gloucester - several corporations had abandoned, even before the execution of the king in January 1649 , the dating of their meetings by the regnal year. There is evidence that even in remote Wales the new style of calendar was sometimes used thereafter ${ }^{47}$. More

${ }^{43}$ Acts and Ordinances, I. 966, II. 1096; letters to and from Lenthall, G. R. O., Letter book, 48, 74-76, H. M. C., 13th Report, I. 61-62, 71. News of the Act for sale of dean and chapter lands reached the corporation two months before it became law, Corp. minute book, 496. Lamprey pies were regularly sent from the city to the Speaker, his nephew and Pury, at Westminster, ibid., 493, 594.

${ }^{44}$ Ibid., 583; Dorney, Certain Speeches, 54.

45 W. R. Williams, The Parliamentary History of the county of Oxford; idem, ... Gloucester; idem, ... Worcester.

${ }_{46}$ Worden, The Rump Parliament, 36.

${ }^{47}$ G. R. O., Corp. minute book, 448, 461, 701; Oxford Council Acts, 163; register of apprentices at Gloucester changes from Latin to English in May/June 1651. D. and $R$. Hook, More light on John Davies of Kidwelly, in: Carmarthenshire Antiquary (1979) 58-59. I am grateful to Dr. David Hook for this reference. 
significantly, the assembly portrayed on the seal was mirrored in a hundred common councils through the length and breadth of England. Within Parliament the House of Commons reigned alone: it was a small body, with seldom more than $\mathbf{8 0}$ members attending in the years after the revolution; above it was placed a smaller, nominated, executive, the council of state ${ }^{48}$. The government of the cities was comparable: a council from 50 to 120 strong, which devolved power on the mayor's council of twelve. And the town halls, in a similar manner, had divested themselves of all rival authorities within the boundaries of their jurisdiction.

The major constitutional alteration in the years of the republic was the establishment of the Protectorate under Oliver Cromwell. The seal of the new regime (see illustration 2) pictorially represents some aspects of the change which occurred in 1653 . The Lord Protector is shown as Renaissance military commander, fully armoured, on horseback and carrying the marshal's baton. London lies at his feet. Around the seal the inscription, in imitation of the old royal style, unites the three nations under his rule. The new element of personal, though limited and uncrowned, monarchy is displayed: Cromwell's own family arms were placed at the centre of the Protectoral shield which carried the harp of Ireland, the cross of St George and the saltire of Scotland. The corporations were to adapt themselves to these changes too. Cromwell, after the battle of Worcester, was invited to become the high steward of Gloucester. Dorney sang his praises ${ }^{49}$. Each town was, in its own way, to come to some accommodation with the phenomenon of the rule of the Major Generals. The cities, as we have seen, returned officers, some with Oliverian connections, to the Protectorate Parliaments.

\section{V}

Even with the cooperation of the new regime which had, in some cases, placed them in power, the ruling elites in the towns faced a daunting task: how to restore unity and order in the civic commonwealth, make good the heavy physical and economic losses of the war, and promote a godly reformation now that the old hierarchy, like many of the parish churches in the towns themselves, was thrown down. It would be unsurprising if many councillors, having reached positions of authority they would not have expected to occupy under normal cirumstances, viewed the prospect with dismay. Urban communities, outside the southeast, may have suffered disproportionately in the civil war. Most in the war zones lost their extra-mural suburbs, as outlying defences were constructed there or besiegers razed them to the ground. Bombardment and fire, deliberate or accidental, caused destruction within the walls. A fifth of Gloucester's housing stock was lost in the preparations for the siege and the siege itself; a similar proportion, mainly of poorer dwellings, was burned in the great fire at Oxford of 1644. A quarter of Chester's houses were destroyed. Houses outside the gates at Worcester were pulled down, and much damage was caused by the Scots in 1651 , and

48 Worden, The Rump Parliament, app. A.

19 Wasbboum, Bibliotheca Gloucestrensis, 409-411, Dorney, Certain Speeches, 75. 


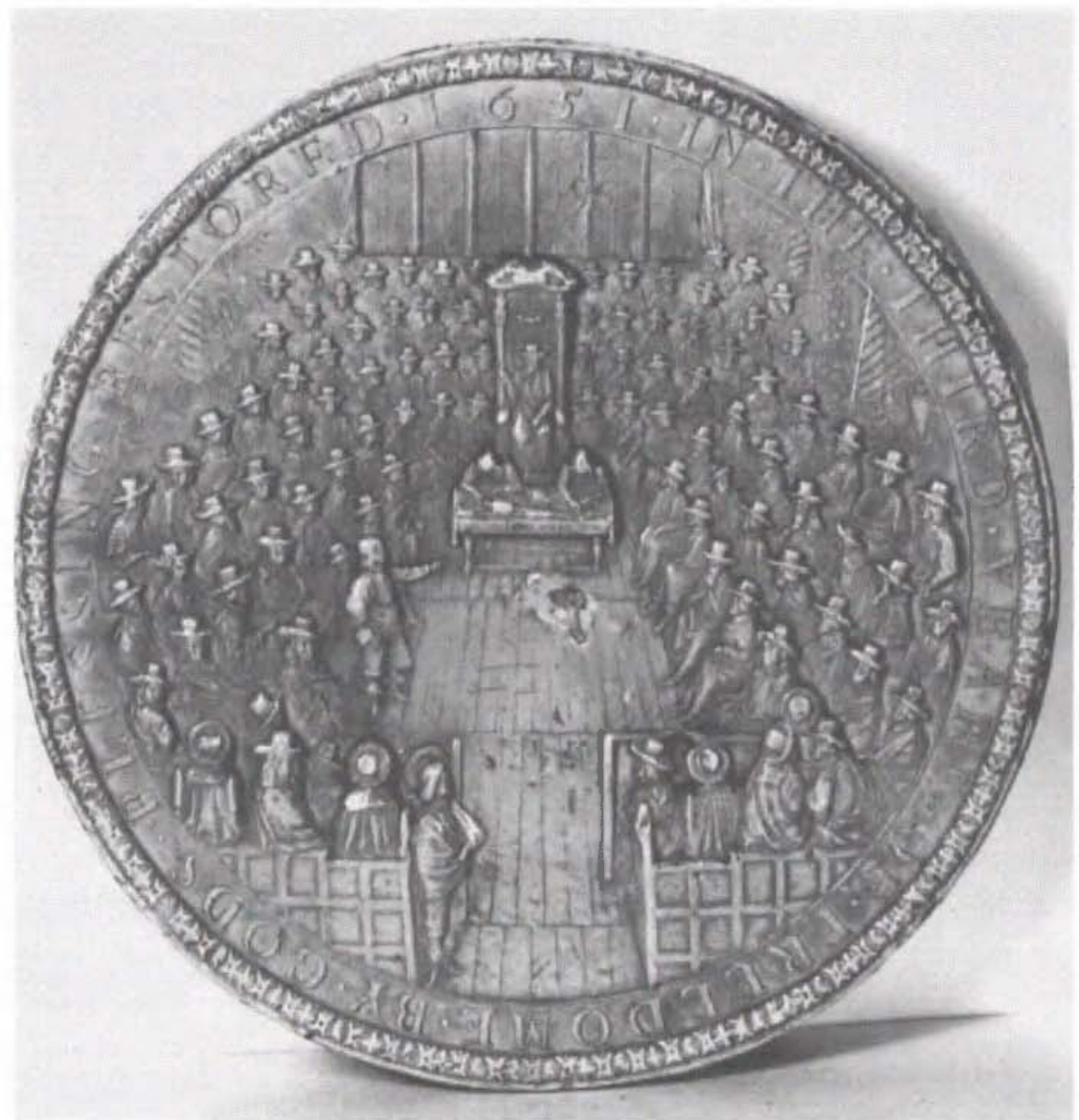

Plate 1: The Commonwealth Seal of 1651, British Library, Seal XXXIV 17

in the aftermath of their defeat ${ }^{50}$. Town churches were particularly vulnerable; employed in emergencies as foodstores, arsenals, and - if they possessed towers - as gun emplacements, their bells and communion plate melted down to provide gunmetal and coin respectively, they were often the target for enemy fire. When reduced to rubble their stone was taken to patch the defences. Churches at Gloucester and at Oxford were used, to their great damage, as temporary - and overcrowded - prisons ${ }^{51}$.

As damaging were the economic and human losses to the towns most closely in-

so Wasbbourn, Bibliotheca Gloucestrensis, 379-387; G. R. O., Letter book, 136; Styles, Worcester, 233; Jobnson, City of Chester, chap. 7; S. Porter, The Oxford Fire of 1644, in: Oxoniensia XLIX (1984) 289-300.

s1 E.g., St Mary de Lode church at Gloucester, G. R. O., Letter book, 136; Corp. minute book, 459. 


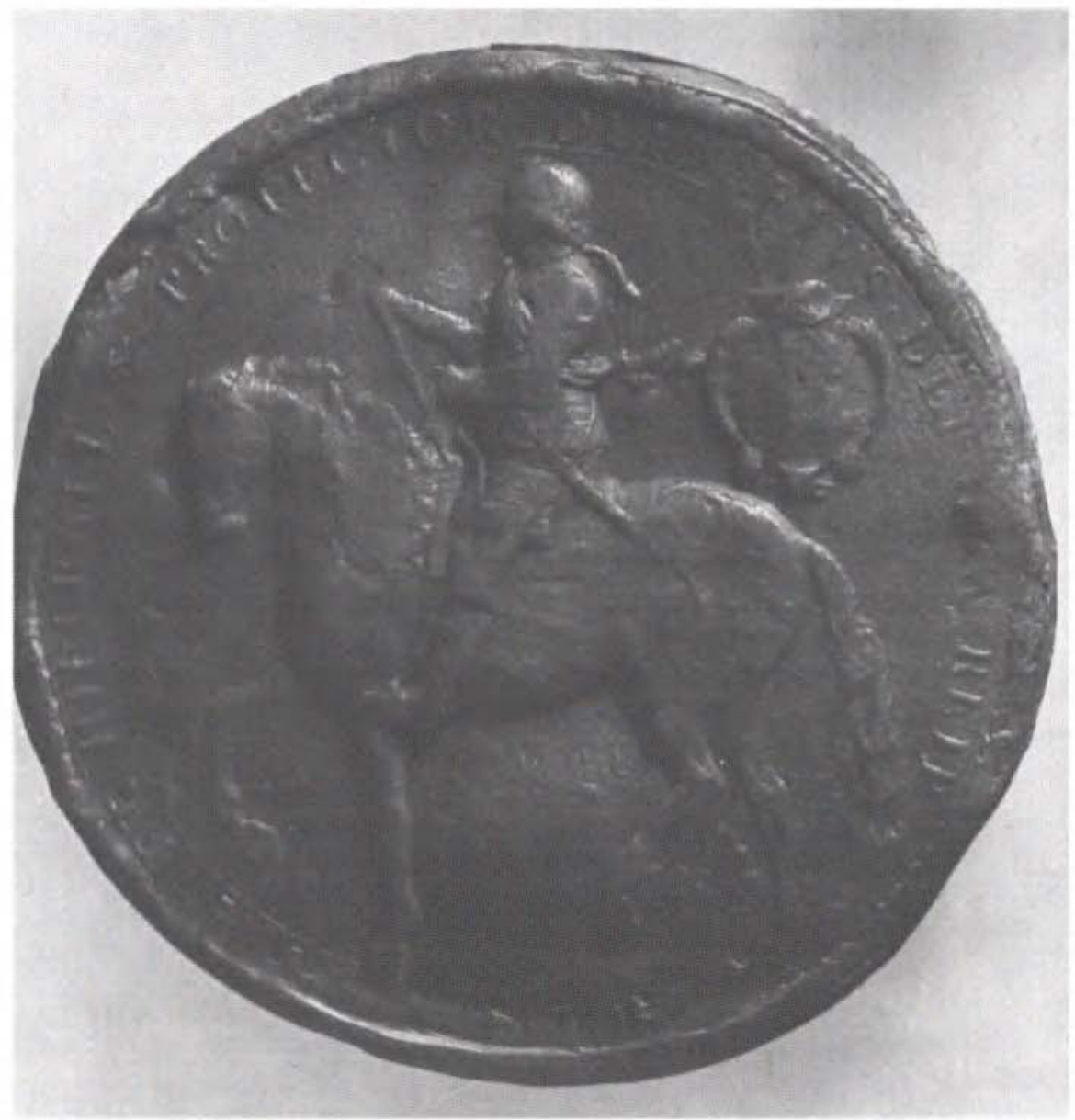

Plate 2. The Protectorate Seal, British Library, London, Seal XXXIX3

volved in the wars. As garrisons and military headquarters, and as strongholds in a devastated battle zone, they attracted refugees in addition to the occupying force: in the resulting overcrowded and insanitary conditions disease and disorder were rife during the 1640s. The mortality rate at Oxford climbed to five times its pre-war level; the plague which broke out at Chester following the war had a devastating impact; Elvins, returning to Worcester after the battle of 1651 , risked his life among the 'sick Scots' who were imprisoned there ${ }^{52}$. There was an equally damaging interruption to the trade and industry of urban areas, as market towns were cut off from the districts they

${ }^{52}$ See generally I. Roy, England turned Germany? The aftermath of the Civil War in its European context, in: Transactions of the Royal Historical Society, 5th ser., vol. 28, 127-144; Johnson, City of Chester, 219; Styles, Worcester, 242. 
served, carriers and farmers bringing goods for sale were plundered, and heavy military taxation, even in parts of the country otherwise spared, reduced economic activity. Most corporations were forced to raise loans on the security of the city's seal and ran into debt to pay for fortifications, munitions, the wages of the garrison and gifts to the governor $^{33}$.

The councils which faced these problems after the war had not been immune to the dangers involved: their membership had been reduced by death, illness and bankruptcy as well as the direct political interference, already considered. At Worcester, for instance, a harsh military regime during the war had taken its toll: the council, at some meetings, was halved in strength, and after 1651 the government of the city almost collapsed $^{54}$. As Table 1 shows, only two meetings of the ruling body were held in the year following. Yet in this city, which was far from united in its devotion to the cause of Parliament, recovery from the damaging effects of the war was swift, and under the leadership of Edward Elvins the council, displaying remarkable energy and commitment, seized the opportunities offered by the Commonwealth and the Protectorate to extend the boundaries of its jurisdiction, restore the economic health of the city and undertake, so far as it was able in the time available, a reformation of the preaching ministry. According to the historian of the city, Elvins, in this role, typified 'that combination of efficiency and zeal which were both a cause and an effect of the Parliamentary victory'35. He was helped by the buoyancy of Worcester's clothing industry, and the power which the magistrates now had, in the $1650 \mathrm{~s}$, to make use of the sequestrated revenues of the church lands and even parts of the cathedral. In order to augment the revenues of the local preachers the 'leaden steeple', a detached belfry in the cathedral grounds, was sold for building materials. The city's debts were paid off, and Elvins himself, after a long campaign, was personally rewarded by Cromwell's government in 1655 , with the sum of $£ 600$, to compensate for his losses in the service of his city. $\mathrm{He}$, and the authorities at Gloucester, were less successful in obtaining the more general reparations they both claimed for the damage suffered during the war at the hands of the Royalists ${ }^{56}$.

Oxford too had been gravely weakened by the war, and the near bankruptcy of many of the colleges as a consequence of the Royalists' failure to pay their bills, and the departure of the students until peacetime conditions returned. The corporation had been subject to bitter political disputes, as petitions and counter-petitions rained on Parliament, and councillors almost came to blows in the chamber ${ }^{57}$. But, as at Worcester, recovery was surprisingly rapid; the factors which had made the city expand

${ }^{53}$ Roy, England turned Germany?; G. R. O., Corp. minute book, 460, 887; Town clerk's book, f. 193, Chamberlains' accounts, 1653-63,210 (Gloucester corporation was $£ 2000$ in debt by 1658); Bond, Chamber Order Book, 38, 370; Styles, Worcester, 222-233.

s4 Worcester petition, P. R. O., SP 24/86; Styles, Worcester, 250-251.

55 Ibid., 241.

56 Ibid., 242-243; Acts and Ordinances, II. 1134; Wasbbourn, Bibliotheca Gloucestrensis, 386-387.

${ }^{57}$ Oxford Council Acts, 151-159, 231-232, 429, 432; Bodleian, Wood F 35, f.13; P. R. O., SP 24/ 13, f.38v. 
and prosper before the civil war were again in evidence. The remodelled university entered a period of constructive reform and productivity, following the Visitation of 1648 , when many of the king's adherents among the fellows were expelled. John Nixon, mayor for the fourth time, at the age of sixty-five, in 1654, presided over the city's revival. The university had already been forced to make concessions to the townsmen, on the right to the market tolls, and the St Scholastica's day ceremonies, before the civil war. Nixon and his fellow councillors pressed home their attack on the academics' privileges with renewed vigour in the Interregnum, confident of the support of the new regime in their refusal to take part in ceremonies which could be described by Puritans as superstitious and 'popish'. In the 1650 s the citizens reclaimed the night watch and the tolls, and frustrated the sitting of the university's courtleet in the town hall. A more enduring legacy of these years, however, was Nixon's grammar school, founded in $\mathbf{1 6 5 8}$ in the courtyard of the town hall itself, entrance to which was confined to his own kin and that of other freemen of the city. It survived until the end of the nineteenth century ${ }^{58}$.

As might be expected, Puritan zeal and effectiveness, in tackling post-war problems and in seizing the opportunities presented by the republican regimes in these years, are best seen at Gloucester, where the aldermanic bench provided strong leadership, based on a long tradition of militant Protestantism, continuity of membership and a near monopoly of wealth in the city. Gloucester's civil war record made it a favoured child of the revolution, whatever the changes of government at the top; and there are signs that the republic, rather coldly welcomed in the city on its first appearance, began to be viewed more warmly as the years passed. Dorney had asked his hearers to judge the strange new regime by its results; and as the victories of Cromwell and Blake, by land and sea, showed that the infant Commonwealth could defend itself against its enemies, its prestige grew at home ${ }^{59}$. While ideas of republicanism remained vague and largely unexplored, despite Milton's voluminous writings, at least it was increasingly clear that those who had laid impious hands on the Lord's anointed would not, in the event, be consigned to outer darkness. A Protestant 'free state' (the term was becoming current in the 1650 s) was seen to be effective in commercial and military terms. It is worth recalling that Robert Blake was a townsman of merchant stock, who liked nothing better than to converse in his cabin, while at sea, about the affairs of his home town of Bridgwater ${ }^{60}$.

If external threats could be subdued, what of those nearer home? Dorney no doubt expressed the worries of the Puritan magistracy that the revolution would usher in "the great inconveniencies of Anarchy or the Levelling way ${ }^{\text {c61 }}$. The death of the king

58 V.C.H., Oxfordshire, I, 474, IV, The City of Oxford, 155-173, 444; Oxford Council Acts, 136-137, 141, 171-174, 203, 273-274, 363, 402-403; Oxford City Library, E.4.3 (suits with the university, 1634-80) 30-55: 'Grosse superstition' referred to on p. 32.

39 Dorney, Certain speeches, 58, 66, 70, 78-79.

60 Worden, The Rump Parliament, 252-253. Blake was a native of Bridgwater, where his family were office-holders and benefactors. His brother was mayor in 1647, and he was M.P. 1646-53, 1654-55. C. D. Curtis, Blake: General-at-Sea (Taunton 1934) 161-162, 167, 173.

${ }^{61}$ Dorney, Certain Speeches, 53. 
had raised millenarian expectations thoughout England, and Gloucester was doubtless no exception. In 1644 the city, after a public debate between a mainstream preacher and an antinomian, had briskly expelled the latter, marching him as far as Sudeley, the better to avoid the contagion of his beliefs ${ }^{62}$. The threat from the Levellers, and from the growing number of sects, was taken seriously by the Rump, as it was locally. The town clerk was able, in 1650 , to give a welcome to the 'many good new laws' passed by Parliament, to limit freedom of worship and the expression of 'heretical' beliefs. He was reassured also by the crushing of the Levellers, and Cromwell's acceptance of the Chancellorship of Oxford University, in the following year. „Some do much doubt", he said, "that this Common-wealth will come much short of the glory this Nation had whilest it was a Kingdom, because they suppose the great luminary of knowledge will be ecclipsed by the interposition of some that are all for changes, and to bring things to a levell. ${ }^{\text {“63 }}$ Cromwell as Protector of learning in the Oxford schools answered these doubts. Unlike Bristol, Hull and York, where the sects had the support of the local garrison commander, Gloucester's ruling elite was able to keep a tight grip on religious practice throughout the 1650 s.

The city was indeed a microcosm of that second Protestant reformation undertaken during the Interregnum by those Puritan magistrates who considered that the first reformation had been only half completed. The legislative framework provided by Parliament after the civil war gave to the town hall - the aldermen as justices of the peace and as members of key committees for the county - full power to reorder the ecclesiastical organisation of the city, following the abolition of episcopacy, the sale of bishops' lands and the takeover of dean and chapter estates. The need was great, for several churches were fire-damaged or ruined, the cathedral stood gaunt and empty, and many of the original incumbents had fled. The bishop's palace had been plundered, the bishop - the harmless eccentric, and Catholic, Goodman - reduced to beggary, while the outbuildings had been taken over by the homeless poor ${ }^{64}$. The old problem of too many parishes, with poor livings, was intensified. By the Parliamentary ordinance of 3 April 1648, „for uniting certain churches and for maintenance of preaching ministers in the city of Gloucester", steered through Parliament by Pury, the eleven parishes of the city were reduced to four. Four 'grave and orthodox divines', including the well-known Help-on-high Fox, were selected by the corporation. They were given empty prebendal houses in the cathedral close, and revenue from sequestrated cathedral property which had been reserved for 'pious uses' ${ }^{3}$. The city now controlled many of the rights to present to livings, and to collect tithes, once held by local landlords, the bishop and the dean and chapter. It reorganized and improved the adminis-

62 Wasbbourn, Bibliotheca Gloucestrensis, XCII, CLXXXIII-IV; Clark, 260.

${ }^{63}$ Dorney, Certain Speeches, 66, 70, 75; Worden, The Rump Parliament, 120-123, 213-216.

${ }^{64}$ G. R. O., GBR 1916 and 1916A, undated petitions from Goodman and the City; Parliamentary survey of bishop's palace, Feb. 1648, GDR G 3/19. ff. 48-49.

${ }^{65}$ Wasbbourn, Bibliotheca Gloucestrensis, 359-366; Worden, The Rump Parliament, 120. Ten parishes were united into four; the eleventh was later joined to the cathedral. G. R. O., Corp. minute book, 455-460, 465-466, 511, 583-584, 764-765; Parliamentary survey of dean and chapter land, 1649, GDR D 936 E/1, 270-280. 
tration and income of the city's hospitals, in recognition of the growing number of poor and needy. Finally, the cathedral itself, which had only occasionally been used for sermons and public debates, such as the one over antinomianism in 1644 - was repaired by subscription (a cause Dorney had long been advocating) and taken over by the city authorities in 1657 . Thomas Pury, junior, who had been living in the deanery since 1648 , furnished the college with a public library at his own expense ${ }^{66}$.

The ecclesiastical and other reforms carried out by the city elite reinforced the power and prestige of the corporation at Gloucester. The members of the aldermanic bench had a major share in the favourable leases of church lands; Thomas Pury, senior, was repaid the loans he had advanced to the state during the war, from the same source. Materials from disused churches, and their bells, and even a broken bronze cannon from the defences, were sold for the benefit of the corporation ${ }^{67}$. The new preachers and the magistrates gave each other mutual support. The corporation was the patron not only of the four united churches, but of the reorganized schools and hospitals. From 1653, with the introduction of civil marriage, the magistrates officiated at weddings in the city. They paid for extra weekly lectures, and sermons to hospital inmates, by the ministers. The high point of the week, and an occasion for civic pageantry, was the Sunday service held at the cathedral, to which the mayor and the full council processed in their gowns from the town hall. There they heard sermons which extolled the "benefits of magistracy" and condemned radical sectarianism as "diametrically opposite both to magistracy and ministry ${ }^{\text {c6s }}$. They enforced a strict orthodoxy in their civic commonwealth throughout the 1650s, for there is little sign at Gloucester of that Quaker and other religious activity which increasingly attracted attention in these years. To accommodate the growing volume of council business one of the redundant parish churches was converted into a new 'tolsey' or town hall: 'a stately structure', according to the town clerk in 1650. There, taking the place of the old church discipline, the mayor's court punished those not attending divine service, and supervised generally the morals of the Gloucester citizenry. They banished a visiting puppet show; but in 1656 allowed musical performances to be resumed in the city ${ }^{69}$.

${ }^{66}$ G.R. O., Letter book, 138; Corp. minute book, 461, 545, 887; Parliamentary survey of dean and chapter land, 267-269. The plan to turn the chapter house into a library was first mooted in 1646. Corp. minute book, 381; it was complete by July 1654 when John Evelyn visited it and described it as a 'noble tho' a private designe'. Wasbbourn, Bibliotheca Gloucestrensis, CLXV; Dorney, Certain speeches, 82 . On the final transfer of the cathedral to the corporation see Corp. minute book, 752-753, 875, 878-879, 881 (the council took the precaution of printing their vote of Aug. 1656); the Act was June 1657, Acts and Ordinances, III. CII.

${ }^{67}$ G.R.O., Corp. minute book, 460, 475, 547, 584, 700, 887; the survey of dean and chapter land shows beneficial rents awarded to prominent individuals: Thomas Pury, senior, had been a leaseholder before the war; survey, 25, 87, 132-133, 138-140, 269.

${ }^{68}$ G.R.O., Town clerk's book, f. 63; Corp. minute book, 503-504, 887; Acts and Ordinances, II. 715-718; Dorney, Certain speeches, 53, 66. Quaker principles were condemned in these terms in Parliament in 1657, Diary of Thomas Burton, I. 137.

${ }^{69}$ G.R.O., Corp. minute book, 459, 460, 475, 510-511; both Purys were connected with this project, 460, 547, 572. Dormey, Certain speeches, 66. On Sunday observance, the Act of April 1650, Acts and Ordinances, II. 383-387, gave power to J.P.s to make search for defaulters: Town clerk's book, ff. $55,59,61,64,66,67,73,80,81$; Corp. minute book, 590, 891. 
On the whole the magistrates were successful in strictly regulating the life of the city. They were busy and practical, upholding civic dignity while promoting a Cromwellian reformation of manners. What they could not do, however, was to turn the tide of economic adversity which had been running against their city for decades. The cloth trade continued to decline, and severe war damage and disruption worsened the situation. Measures to relieve the swelling ranks of the poor and stem the tide of vagrants, largely of Welsh origin, were all the more necessary. These social and economic pressures sharpened the old quarrel with the gentry of the 'inshire', that part of the county anciently under the jurisdiction of the city. Former disputes over the share of taxation borne by shire and city resurfaced, and Dorney noted that many of the wealthiest of the inhabitants of the shire were 'cooled in their affections' to the city. One blamed the policies pursued by the town hall for their economic plight ${ }^{70}$. The steady recovery of their estates by the gentry and the reassertion of their power under the Protectorate - several were named to the new commissions for assessment after 1653 - disadvantaged the city. Even when the garrison was removed the burden of soldiers' families left on the parish remained; ex-soldiers were practising trades in the city, though 'foreigners'; and the long promised compensation for war damage never materialised $^{71}$.

\section{VI}

That increasingly influential groups were dissatisfied with the pretensions of some civic authorities, and their conduct of affairs, and a much larger number of the populace, in a Puritan city like Gloucester, resented the scrutiny, interference and punishment to which they were subject, was a pointer to the future. In towns where the postwar elite was less well rooted than at Gloucester, there was an alternative party of councillors, temporarily proscribed, ready to take over, and to provide encouragement for popular resentments. The town hall regimes of the 1650 s had weathered the storms of the civil war and the many vicissitudes of the years that followed, and had, in most cases, established good working relationships with the successive governments of the Interregnum. They had won many advantages for their communities after the downfall of the crown, church and many of the gentry. But they had built up undying resentments thereby, and a good deal of popular hostility, which found expression in the celebration of Christmas and other ways: at Oxford, for instance, the students demonstrated at the proclamation of Richard Cromwell in $1658^{72}$.

${ }^{70}$ Dorney, Certain speeches, 22, 57-58, 79-80. 'Great decay of trading' complained of in 1659 petition, G.R.O., Letter book, 262. The 1655 dispute between the city and inshire reported ibid., 184-194, 203, and Corp. minute book, 769-70. See also Davies, Guise of Elmore, 104.

${ }^{71}$ See lists of commissioners of 1657, Acts and Ordinances, II. 1058-1097. On the garrison, and the delusion of compensation out of Irish land, see Dorney, Certain speeches, 27, 79-82; Wasbbourn, Bibliotheca Gloucestrensis, 386-387, 408-409, 417-418; Acts and Ordinances, II. 722-753.

${ }^{72}$ A. Clark (ed.), The Life and Times of Anthony Wood ... of Oxford (Oxford 1891) I. 259. 
When, within less than a year of Cromwell's death and his son's accession, the Protectorate collapsed, the rival ambitions of its successors led, not, as Milton had hoped, to a better prepared for and more principled spell of republican government, but to a period of political instability, which was brought to an end by the least expected development of all, the restoration of the king. The thoughts of the duke of Newcastle, to which we can now return, will exemplify the outlook of many of the Royalists in exile, who crowded home in 1660 to enjoy the fruits of a victory they had long awaited but had contributed almost nothing towards. His view of the corporations in England was no doubt moulded by his experience of the resistance he had encountered, almost twenty years before, as Royalist commander of the north, in the Parliamentarian West Riding clothing towns. An important component of that resistance had been a more militant or zealous brand of Protestantism. Newcastle's opinion took little account of the political and religious developments of the years since the civil war, and the widespread inculcation of mainstream Puritanism in many areas. Charles II and his chief adviser, Clarendon, made at first only vague promises concerning the restoration of, for instance, episcopal and dean and chapter lands: they treated the representatives of the broad consensus of political and religious opinion associated with the Protectorate whith caution and respect. But the restoration developed a momentum of its own, with the return of more ardent Royalists from abroad or from a self-imposed internal exile' at home. The wishes of the king and minister were overtaken by the Anglican gentry and churchmen who now ordered affairs in their own localities.

As they had been, in many cases, the main sufferers at the hands of the corporations during the Interregnum they were anxious to settle old scores. They were soon in a good position to do so. Most cathedral chapters had been restored by August 1660, and Cavalier gentry and church property recovered. Several towns, such as Oxford, were forced to invite locally dominant peers and gentry to become freemen and councillors; and they soon began to exercise patronage there on behalf of their clients ${ }^{73}$. They dominated the elections to the new Cavalier Parliament. By the Act of Uniformity and the Corporation Act, early measures of that Parliament, nonconformist clergy were expelled, and the town halls purged. The task of placing the corporations in politically safe hands was given to the local gentry, who manned the commissions which investigated each borough. That for Gloucester contained leading inshire families and was headed by a hardline Royalist peer ${ }^{74}$. By March 1663 , when their work was complete, not only all councillors who had refused the oaths tendered - and the repudiation of old Parliamentarian ones - but any others who, for any reason, were unacceptable to the commissioners, were removed. Tables 2 and 3 show the extent of the Restoration purges. Worcester's council collapsed immediately, one of its members fleeing for his life: Elvins and others were quickly replaced by those who had themselves lost

${ }^{73} \mathrm{~J}$. Habakkuk, The land settlement and the Restoration of Charles II, in: Transactions of the Royal Historical Society, 5th ser., vol. 28, 202-222; Oxford Council Acts, 274-276, 305-306.

${ }^{76} \mathrm{~J}$. Miller, The crown and the borough charters in the reign of Charles II, in: English Historical Review C (1985) 53-84; papers relating to the commissioners' work at Gloucester were entitled 'oath of the Solemn League, 1662-88', G.R.O., GBR 1470. 
their posts in the Interregnum. By 1663 two-fifths of the previous council had departed $^{75}$. The purge at Gloucester was even more severe. Two-thirds of the council 38 councillors out of 59 - and the town clerk, Dorney, were displaced. Thomas Pury, senior, left the city, before the blow fell, for the relative anonymity and safety of London, but he was pursued in the law courts by the dean and chapter until his death a few years later. There was an almost clean sweep of the city's ruling elite, many of whom had held power since before the war: only two of the original twelve aldermen remained on the bench ${ }^{76}$. At Oxford 31, including four who had been mayor in the 1650 s, and Nixon's protege as town clerk, were removed: a quarter of the council. Nixon himself narrowly avoided humiliation in the city of which he was such a notable benefactor, by dying in April $1662^{77}$. As can be seen from Table 3 the removals of 1660-3 account for the biggest changes in council membership, expressed as a percentage of all departures in the period 1635-65: only deaths in wartime Oxford come close. Where the political displacements of the civil war and Interregnum had been small-scale and piecemeal, although cumulatively significant, the Restoration brought immediate, systematic and large-scale changes. So deep were the cuts that the commissioners, in some cases, ran out of suitable replacements. At Gloucester 'custom and charter' were set aside to allow those not properly qualified to take their seats on the council. Several were clients of the county gentry; others professional men living in the cathedral close rather than long established citizens and tradesmen ${ }^{78}$.

The resumption of their traditional role in local government by the gentry and clergy inevitably meant a reduction in the competence and power of the urban magistrates. They lost prestige in other ways: in 1661, a little belatedly, the corporation of Oxford offered its annual obeisance to the university again. The gates of Gloucester, which had been closed to the king in 1643 , were carried off and presented to Worcester, which was quickly creating the legend that it had been unswervingly loyal. A spate of new charters following the work of the commissioners further diminished municipal autonomy, for the first time specifying by name who should occupy the key posts of town clerk and recorder. The 1664 charter for Gloucester significantly removed the inshire, on the petition of the gentry there, from the jurisdiction of the city ${ }^{79}$.

One cannot escape the conclusion that, if the towns here studied were at all representative, corporations throughout England were being punished for their misdeeds during the period of republican rule. But were they culpable in the matter of the king's death and the abolition of the monarchy and the House of Lords? None of the leading citizens whose careers have been examined in this paper had taken part in those events. But the town halls had seized the opportunities presented by the removal of the independent jurisdiction, and the sale of the property, of rival local authorities in

\footnotetext{
75 Worcester Guildhall, Chamber order book, 3 (1650-69) ff. 37-38.

${ }^{76}$ G.R.O., Corp. minute book, 1656-88, 223-224, 235-240; GBR 1470.

77 Oxford Council Acts, 292-294.

${ }^{78}$ G.R.O., GBR 1470, f. 11; Corp. minute book, 1656-88, 239-240; complaint of mayor in 1671 that wealthiest citizens had been excluded, C.S.P.D., 1671, 411-412.

${ }^{79}$ Oxford Council Acts, 275-276, 282-283; Styles, Worcester, 257; G.R.O., DA/Glos, Box 44, bundle 5 .
} 
church and state, to cooperate closely with the republican regimes in order to further their own interests. Anxious to forward a godly reformation and to extend their own power they had proved zealous and efficient: the united churches, extra lectureships, public library and stately new town hall at Gloucester, and Nixon's freemen's school in the town hall yard at Oxford, are examples of their successful endeavours. Inevitably they produced a reaction. A resurgent Anglican Royalism, sharing an exile's simplistic view of corporations and their lecturers, intervened decisively at the Restoration. The government of corporations had become a matter of political controversy, and the stage was set for later constitutional battles. This was perhaps the most enduring legacy of the relations between the town halls and the English republic. 
